\title{
Analisis Kemampuan Aplikasi Metode Kalender Keluarga Berencana Wanita Usia Subur (WUS) Dalam Menentukan Masa Subur Di Puskesmas Balowerti Kota Kediri
}

\author{
Erma Retnaningtyas, Fitri Astutik, Anisa Fajar Wati, Sariyati Malo \\ Institut Ilmu Kesehatan STRADA Indonesia \\ Corresponding author: Erma Retnaningtya (erma.retna26@gmail.com) \\ Received: December, 16 2019; Accepted: January, 19 2020; Published: March, 152020
}

\begin{abstract}
ABSTRAK
Bagi yang menginginkan kehamilan, masa subur biasa dijadikan patokan untuk melakukan hubungan seksual karena saat ini ovulasi sedang tejadi sehingga kemungkinan hamil sangat besar. Desain penelitian ini menggunakan analitik korelasional dengan menggunakan pendekatan cross sectional. Populasi sebanyak 60 wus dengan menggunakan teknik accidental sampling diperoleh responden 52 responden. Hasil penelitian pada 52 responden didapatkan hampir setengah dari responden berpengetahuan kurang sebanyak 24 orang (46,2 $\%$ ), hampir sebagian besar dari responden tidak dapat menentukan masa subur sebanyak 32 orang $(61,5 \%)$, sebagian besar dari responden tidak dapat melaksanakan aplikasi keluarga berencana sebanyak 36 orang $(69,2 \%)$. Hasil analisa dengan uji regresi logistic didapatkan penentuan masa subur dengan nilai $\mathrm{p}$-value sebesar 0,000 atau $<0,05$ dan pengetahuan dengan nilai $\mathrm{p}$-value sebesar 0,000 atau $<0,05$ sehingga $\mathrm{H}_{1}$ diterima dan Ho ditolak yang artinya ada hubungan antara penentuan masa subur dan tingkat pengetahuan dengan aplikasi keluarga berencana.
\end{abstract}

Kata Kunci: Pengetahuan, Penentuan Masa Subur, Aplikasi Keluarga Berencana

This is an open-acces article distributed under the terms of the Creative Commons Attribution-ShareAlike 4.0 International License.

\section{PENDAHULUAN}

Masa subur adalah suatu masa dalam siklus menstruasi perempuan dimana terdapat sel telur yang matang yang siap dibuahi, sehingga bila perempuan tersebut melakukan hubungan seksual maka dimungkinkan terjadi kehamilan. Masa subur sangat berarti bagi mereka yang menginginkan kehamilan dan bagi yang menunda kehamilan. Bagi yang menginginkan kehamilan, masa subur biasa dijadikan patokan untuk melakukan hubungan seksual karena saat ini ovulasi sedang tejadi sehingga kemungkinan hamil sangat besar. Sedangkan bagi yang mau menunda kehamilan, masa subur merupakan masa yang harus dihindari untuk mencegah terjadinya kehamilan (Indarti, 2011).

Kesuburan merupakan kunci dari kehamilan. Namun tidak semua perempuan tahu cara mendeteksi masa suburnya sendiri (Sugi suhandi Iskandar, 2007). Pada tahun 2001 American Infertility Association mengadakan kuisioner terhadap 12.383 orang wanita tentang masalah 
kesuburan. Dari jumlah tersebut hanya 1 orang wanita saja yang bisa menjawab hampir semua pertanyaan dengan benar (Yulia Dian, 2006).

Menurut data Biro Pusat Statistik (BPS) di Indonesia, diperkirakan terdapat 12\% pasutri yang tidak dapat memperoleh keturunan dalam 1 tahun (Infertil). Survey Demografi dan Kesehatan Indonesia (SDKI) 2003 menemukan data bahwa pengetahuan yang benar tentang siklus reproduksi sangat terbatas. Hanya 16 persen wanita pernah kawin dan wanita berstatus kawin memberikan jawaban yang benar tentang periode yang tepat ketika wanita mempunyai kemungkinan terbesar untuk menentukan masa subur, yaitu pada pertengahan siklus ovulasi (BKKBN, 2013).

Pengetahuan dasar mengenai fisiologi reproduksi berguna untuk keberhasilan menentukan masa subur pada penghitungan masa subur dan aplikasi masa subur. Berdasarkan Survey Demografi Kesehatan Indonesia (SDKI) tahun 2012, semua wanita ditanya mengenai pengetahuan mereka tentang masa subur pada wanita. Hanya 18 persen dari semua wanita umur 15- 49 yang mengetahui masa subur terjadi di antara dua periode menstruasi. Diantara responden 50\% dapat menjawab dengan benar mengenai masa subur. Secara umum, hasil ini menunjukan perlunya pengetahuan dan pendidikan mengenai fisiologi reproduksi dalam meningkatkan efektivitas penghitungan dan aplikasi masa subur (SDKI, 2012).

Indonesia merupakan sebuah Negara berkembang dengan jumlah penduduk sebanyak 252.124.458 jiwa dengan luas wilayah 1.913.378,68 km2 dan kepadatan penduduk sebesar 131,7 jiwa/km2 (Depkes, 2014). Cakupan peserta KB baru dan KB aktif di Indonesia pada tahun 2014 dengan jumlah Wanita Usia Subur (WUS) sebanyak 47.019.002 (Depkes, 2014).

Penduduk di jawa timur sebanyak 38.268.825 jiwa, memiliki WUS yang memakai alat/cara Keluarga Berencana (KB) sebanyak 24.720 jiwa (Kemenkes, 2013). Pada penggunaan alat kontrasepsi jawa timur menempati urutan ke tiga (72,9\%) (Puslitbang, 2014).

Berdasarkan Studi Pendahuluan pada bulan Maret 2018 di Puskesmas Balowerti didapatkan sebanyak 92 wanita usia subur (WUS). Dari 15 orang Wanita Usia Subur (WUS) yang diwawancarai diperoleh 10 orang WUS yang tidak tahu tentang masa subur serta penghitungan masa subur, dan 5 orang WUS tahu tentang masa subur serta penghitungan masa subur.

Menentukan masa subur tidak bisa diterangkan di masyarakat karena tingkat kegagalan yang tinggi sehingga di kuatirkan dapat menyebabkan kehamilan yang tidak diinginkan dan dapat mengakibatkan tingginya angka ibu hamil resiko tinggi. Mengingat hal ini maka sebaiknya Wanita Usia Subur (WUS) mengetahui tentang cara menghitung masa subur agar bisa melakukan penundaan kehamilan ataupun menginginkan kehamilan baik, sehingga kesehatan reproduksi Wanita Usia Subur (WUS) tersebut tetap aman. Hal ini didasari oleh suatu fakta bahwa kurangnya pengetahuan tentang reproduksi yang aman untuk kehamilan dapat berpengaruh pada kesehatan reproduksi (Wahyu, 2000). Faktor lain yang mempengaruhi perilaku penundaan kehamilan atau keinginanuntuk hamil juga dapat dikaji dari konsep perilaku dalam bertindak. Menurut Green (1980) dalam Notoatmodjo (2003).

Melihat pentingnya melakukan penghitungan terhadap siklus menstruasi dan untuk mengetahui tentang kesehatan yang harus dilakukan, sudah sepatutnya setiap wanita melakuan penghitungan dan mengetahui informasi-informasi tentang penghitungan masa subur pada wanita. Tujuan dari perhitungan masa subur yaitu menilai kejadian dan waktu terjadinya ovulasi ( pembuahan ), memprediksi hari-hari subur yang maksimum, mengoptimalkan waktu untuk berhubungan seksual untuk mendapatkan kehamilan, membantu mengidentifikasi sebagian masalah infertilitas. Permasalahannya adalah tidak semua wanita menandai siklus menstruasinya. Alasannya bermacam-macam, dan beberapa diantaranya dikarenakan seorang wanita karir yang tidak mempunyai waktu untuk menuliskan pada buku agenda ataupun direpotkan dengan pengaplikasian masa subur dalam 
keluarga. Dari fenomena tersebut peneliti tertarik melakukan penelitian tentang "Analisis Kemampuan Aplikasi Metode Kalender Keluarga Berencana Wanita Usia Subur (WUS) Dalam Menentukan Masa Subur”.

\section{METODE}

Desain penelitian merupakan wadah untuk menjawab pertanyaan penelitian atau menguji keaslian hipotesis (Hidayat, 2104). Rancangan penelitian merupakan hasil akhir dari suatu tahap keputusan yang dibuat oleh peneliti berhubungan dengan bagaimana suatu penelitian yang ditetapkan (Nursalam, 2011).

Penelitian menggunakan analitik korelasional dengan menggunakan pendekatan cross sectional menekankan pada waktu pengukuran atau observasi data variabel independen dan variabel dependen hanya satu kali, pada satu saat. Pada pendekatan ini variabel independen dan variabel dependen di mulai secara simultan pada satu saat, jadi tidak ada follow up. Tidak semua subyek penelitian harus di observasi pada hari atau waktu yang sama (Nursalam, 2012). Dalam penelitian ini menganalisis kemampuan aplikasi keluarga metode kalender keluarga berencana wanita usia subur (WUS) dalam menentukan masa subur di Puskesmas Balowerti Kota Kediri.

\section{HASIL PENELITIAN}

1. Tabulasi Silang Antar Pengetahuan Dengan Aplikasi Keluarga Berencana Tabel 4.12 Tabulasi Silang Antar Pengetahuan Dengan Aplikasi Keluarga Berencana

\begin{tabular}{|c|c|c|c|c|c|c|}
\hline \multirow{2}{*}{ No. } & \multirow{2}{*}{$\begin{array}{l}\text { Pengeta } \\
\text { huan }\end{array}$} & \multicolumn{3}{|c|}{ Aplikasi keluarga berencana } & \multirow{2}{*}{$\begin{array}{c}\text { Melaksanakan } \\
\text { Tidak } \\
\text { melaksanakan }\end{array}$} \\
\cline { 3 - 6 } & & $\mathrm{n}$ & $\%$ & $\mathrm{~N}$ & $\%$ & \\
\hline 1 & $\begin{array}{c}\mathrm{Ba} \\
\mathrm{ik}\end{array}$ & 8 & 15,3 & 5 & 9,7 & 13 \\
\hline 2 & $\begin{array}{c}\mathrm{Cu} \\
\mathrm{ku} \\
\mathrm{p}\end{array}$ & 8 & 15,3 & 7 & 13,5 & 15 \\
& & & & & \\
\hline 3 & Kurang & 0 & 0 & 24 & 46,2 & 24 \\
\hline \multicolumn{2}{|c|}{ Total } & 16 & 30,6 & 34 & 69,4 & 52 \\
\hline
\end{tabular}

Sumber : Data Primer 2018

Berdasarkan tabel 4.12 menunjukkan bahwa dari 52 responden didapatkan hampir setengah dari responden tidak melaksanakan aplikasi keluarga berencana sebanyak 24 orang $(46,2 \%)$ dengan pengetahuan kurang.

2. Tabulasi Silang Antar Penentuan Masa Subur Dengan Aplikasi Keluarga Berencana.

Tabel 4.13 Tabulasi Silang Antar Penentuan Masa Subur Dengan Aplikasi Keluarga Berencana

\begin{tabular}{|c|c|c|c|c|c|c|}
\hline \multirow{3}{*}{ No. } & \multirow{3}{*}{$\begin{array}{l}\text { Penentuan } \\
\text { masa subur }\end{array}$} & \multicolumn{4}{|c|}{ Aplikasi keluarga berencana } & \multirow{3}{*}{ Jumlah } \\
\hline & & \multicolumn{2}{|c|}{ Melaksanakan } & \multicolumn{2}{|c|}{$\begin{array}{c}\text { Tidak } \\
\text { melaksanakan }\end{array}$} & \\
\hline & & $\mathrm{N}$ & $1 \%$ & $\mathbf{N}$ & $\%$ & \\
\hline 1 & $\begin{array}{r}\text { Tidak dapat } \\
\text { menentukan }\end{array}$ & 0 & 0 & 32 & 61,5 & 32 \\
\hline 2 & $\begin{array}{l}\text { Dapat } \\
\text { menentukan }\end{array}$ & 16 & 30,8 & 4 & 7,7 & 20 \\
\hline & Total & 16 & 30,8 & $\begin{array}{l}3 \\
6\end{array}$ & 69,2 & 52 \\
\hline
\end{tabular}


Sumber : Data Primer 2018

Berdasarkan tabel 4.13 menunjukkan bahwa dari 52 responden didapatkan sebagian besar responden tidak melaksanakan aplikasi keluarga berencanasebanyak 36 orang $(69,2 \%)$ dengan tidak dapat menentukan masa subur.

\section{Hasil Uji Statistik}

Data-data yang diperoleh selama penelitian kemudian diuji statistik dengan menggunakan Uji Regresi Logistic dengan menggunakan SPSS for windows, yang mana hasilnya adalah seperti dalam tabel berikut

Tabel 4.14 Hasil Uji Statistik Analisis Kemampuan Aplikasi Keluarga Berencana Wanita Usia Subur (WUS) Dalam Menentukan Masa Subur

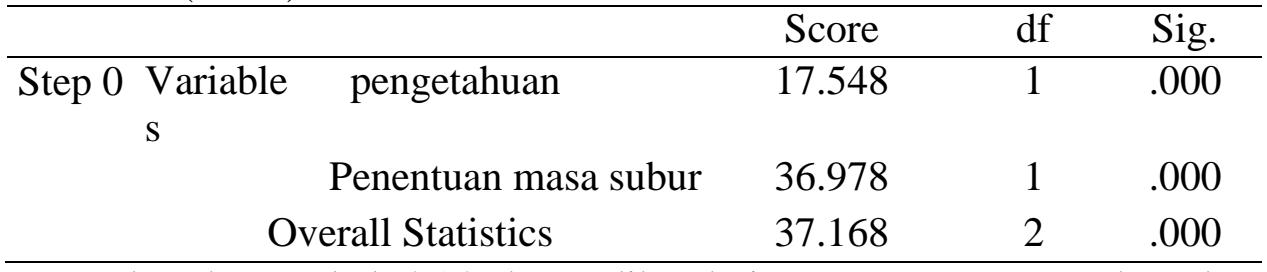

Berdasarkan Tabel 4.14 dapat diketahui penentuan masa subur dengan nilai p-value sebesar 0,000 atau $<0,05$ dan pengetahuan dengan nilai $\mathrm{p}$-value sebesar 0,000 atau $<0,05$ sehingga $\mathrm{H}_{1}$ diterima dan Ho ditolak yang artinya ada hubungan pengetahuan, penentuan masa subur dengan aplikasi keluarga berencana.

\section{PEMBAHASAN}

\section{A. Menganalisis Hubungan Pengetahuan Dengan Aplikasi Keluarga Berencana Wanita Usia Subur Dalam Menentukan Masa Subur}

Berdasarkan tabel 4.12 menunjukkan bahwa dari 52 responden didapatkan hampir setengah dari responden tidak melaksanakan aplikasi keluarga berencana sebanyak 24 orang $(46,2 \%)$ dengan pengetahuan kurang.

Berdasarkan tabulasi silang menunjukkan bahwa dari 52 responden didapatkan sebagian besar dari responden tidak melaksanakan aplikasi keluarga berencana sebanyak 34 orang yang berumur 20-35 tahun (65,4 \%) dengan pengetahuan kurang, hampir setengah dari responden tidak melaksanakan aplikasi keluarga berencana sebanyak 23 orang (44,2 \%) berpendidikan SMA dan sebagian besar dari responden tidak melaksanakan aplikasi keluarga berencana sebanyak 29 orang $(55,8 \%)$ dengan pekerjaan IRT, hampir setengah dari responden melaksanakan aplikasi keluarga berencana sebanyak 16 orang $(30,9 \%)$ dengan metode kalender. Hasil uji analisis dapat diketahui bahwa pengetahuan dengan nilai $\mathrm{p}$-value sebesar 0,000 atau $<0,05$ sehingga $\mathrm{H}$ i diterima dan Ho ditolak yang artinya ada hubungan pengetahuan dengan aplikasi keluarga berencana.

Pengetahuan seseorang biasanya diperoleh dari pengalaman yang berasal dari berbagai macam sumber, misalnya media massa, media elektronik, buku petunjuk, petugas kesehatan, media poster, kerabat dekat dan sebagainya. Salah satu faktor yang mempengaruhi tingkat pengetahuan seseorang adalah informasi yang didapatkan dari tingkat umur, pendidikan, ataupun pekerjaan. Pengetahuan ini dapat membantu keyakinan tertentu sehingga seseorang berprilaku sesuai keyakinan tersebut (Afriyanti, 2011).

Berdasarkan fakta dan teori diatas bahwa pengetahuan dapat mempengaruhi kemampuan aplikasi keluarga berencana dalam menentukan masa subur, karena selama peneliti melakukan penelitian di Puskesmas Balowerti Kota Kediri peneliti menemukan bahwa pengetahuan yang kurang dapat mempengaruhi terhadap kemampuan aplikasi keluarga berencana dalam menentukan masa subur responden karena wawasan yang 
rendah, hal ini perlu dilakukan intropeksi atas penyuluhan-penyuluhan yang telah dilakukan oleh petugas kesehatan agar informasi lebih mudah diterima sehingga dapat meningkatkan kemampuan aplikasi keluarga berencana dalam menentukan masa subur. Dengan pengetahuan mereka yang bertambah meningkat maka diharapakan mereka dapat menganalisis kemampuan aplikasi keluarga berencana dalam menentukan masa subur. Pengetahuan merupakan hal yang sangat penting dalam membentuk pola pikir seseorang. Ibu lebih memilih mengaplikasikan sistem kalender dalam menentukan masa subur untuk keluarga berencana karena tidak memiliki efek samping dibandingkan dengan penggunaan KB lainnya yang memiliki efek samping. Pengetahuan ibu yang kurang dikarenakan ibu tidak ingin mencari tahu dan tidak peduli tentang cara menentukan masa subur.

A. Menganalisis Hubungan Penentuan Masa Subur Dengan Aplikasi Keluarga Berencana Wanita Usia Subur Dalam Menentukan Masa Subur

Berdasarkan tabel 4.13 menunjukkan bahwa dari 52 responden didapatkan sebagian besar responden tidak melaksanakan aplikasi keluarga berencana sebanyak 36 orang $(69,2 \%)$ dengan tidak dapat menentukan masa subur. (30\% miskin), dan banyaknya unmet Berdasarkan tabulasi silang menunjukkan bahwa dari 52 responden didapatkan sebagian besar dari responden tidak melaksanakan aplikasi keluarga berencana sebanyak 34 orang yang berumur 20-35 tahun (65,4 \%) dengan pengetahuan kurang, hampir setengah dari responden tidak melaksanakan aplikasi keluarga berencana sebanyak 23 orang $(44,2 \%)$ berpendidikan SMA dan sebagian besar dari responden tidak melaksanakan aplikasi keluarga berencana sebanyak 29 orang $(55,8 \%)$ dengan pekerjaan IRT, hampir setengah dari responden melaksanakan aplikasi keluarga berencana sebanyak 16 orang $(30,9 \%)$ dengan metode kalender. Hasil uji analisis dapat diketahui bahwa penentuan masa subur dengan nilai p-value sebesar 0,000 atau $<0,05$ sehingga $\mathrm{H}_{1}$ diterima dan Ho ditolak yang artinya ada hubungan penentuan masa subur dengan aplikasi keluarga berencana. Menentukan masa subur dapat diketahui dengan cara melihat dari perubahan menstruasi, perubahan pada lendir servikdan metode suhu basal (Erlina, 2013). Cara menentukan masa subur atau menghitung ovulasi melalui menstruasi yang efektif siklus menstruasinya normal yaitu 21-35 hari. Adapula ahli yang berpendapat antara 22-35 hari. Sel sel keluar pada pertengahan siklus, sekitar hari ke 14 sampai ke 16 dihitung dari hari pertama menstruasi (Erlina, 2013).

Berdasarkan fakta dan teori diatas bahwa penentuan masa subur dapat mempengaruhi kemampuan aplikasi keluarga berencana dalam menentukan masa subur, karena selama peneliti melakukan penelitian di Puskesmas Balowerti Kota Kediri peneliti menemukan bahwa sebagian besar responden tidak melaksanakan aplikasi keluarga berencana dengan tidak dapat menentukan masa subur karena kurangnya pengetahuan, hal ini perlu dilakukan penyuluhan dalam bidang kesehatan dengan cara promosi kesehatan agar informasi lebih mudah diterima sehingga dapat meningkatkan kemampuan aplikasi keluarga berencana dalam menentukan masa subur. Hal ini sejalan dengan teori Erlina karena penentuan masa subur dapat mempengaruhi aplikasi keluarga berencana, yang diperoleh dari pengalaman diri sendiri maupun orang lain baik secara langsung maupun tidak langsung.

Tidak semua wanita menandai siklus menstruasinya. Alasannya bermacam-macam, dan beberapa diantaranya dikarenakan seorang wanita karir yang tidak mempunyai waktu untuk menuliskan pada buku agenda ataupun direpotkan dengan pengaplikasian masa subur dalam keluarga. Melihat pentingnya melakukan penghitungan terhadap siklus menstruasi dan untuk mengetahui tentang kesehatan yang harus dilakukan, sudah sepatutnya setiap wanita melakuan penghitungan dan mengetahui informasi-informasi tentang penentuan 
masa subur pada wanita. Peranan petugas kesehatan diperlukan dalam hal ini dengan tujuan agar wanita usia subur dapat menentukan masa subur yaitu menilai kejadian dan waktu terjadinya ovulasi ( pembuahan ), memprediksi hari-hari subur yang maksimum, mengoptimalkan waktu untuk berhubungan seksual untuk mendapatkan kehamilan, membantu mengidentifikasi sebagian masalah infertilitas dalam keluarga berencana.

\section{KESIMPULAN}

1. Berdasarkan tabel 4.12 menunjukkan bahwa dari 52 responden didapatkan sebagian kecil dari responden tidak melaksanakan aplikasi keluarga berencana sebanyak 5 orang $(9,7 \%)$ dengan pengetahuan baik.

2. Berdasarkan tabel 4.13 menunjukkan bahwa dari 52 responden didapatkan sebagian kecil dari responden tidak melaksanakan aplikasi keluarga berencana sebanyak 4 orang $(7,7 \%)$ dengan tidak dapat menentukan masa subur.

3. Berdasarkan Tabel 4.7 menunjukkan bahwa dari 52 responden didapatkan sebagian besar dari responden tidak dapat melaksanakan aplikasi keluarga berencana sebanyak 36 orang $(69,2 \%)$.

4. Berdasarkan Tabel 4.14 dapat diketahui pengetahuan dengan nilai p- value sebesar 0,000 atau $<0,05$ atau $\mathrm{H} 1$ diterima dan Ho ditolak yang artinya ada hubungan antara tingkat pengetahuan dengan aplikasi keluarga berencana.

5. Berdasarkan Tabel 4.14 dapat diketahui penentuan masa subur dengan nilai pvalue sebesar 0,000 atau $<0,05$ atau $\mathrm{H}$ iditerima dan Ho ditolak yang artinya ada hubungan antara penentuan masa subur dengan aplikasi keluarga berencana.

\section{REFERENSI}

BKKBN. 2013. Laporan BKKBN tahun 2013. Jakarta : BKKBN.

Depkes. 2014. Situasi dan Analisa Keluarga Berencana. Jakarta.

Erlina. M 2013. Bagaimana menghitung dan Menentukan Masa Subur.

Hidayat. 2011. Metode Penelitian Kebidanan dan Teknik Analisa Data. Jakarta : Salemba Medika.

Hidayat, 2014. Metodologi Penelitian Kesehatan. Jakarta : Rineka Cipta.

Indarti. 2011. Panduan Kesehatan wanita. Jakarta : Pustaka Pembangunan Swadaya.

Indarti dan Wahyudi Khotimah, 2012. Buku Babon Kehamilan. Yogyakarta :

Indoliterasi.

Koes, Irianto 2014. Pelayanan Keluarga Berencana. Bandung : Alfabeta.

Notoatmodjo, S. 2012. Ilmu Kesehatan Masyarakat : Ilmu dan Seni. Jakarta : Rineka Cipta.

Nursalam. 2011. Metodologi Penelitian. Jakarta : Rineka Cipta.

Nursalam. 2012. Konsep dan Penerapan Metodologi Penelitian Ilmu Edisi Kedua. Jakarta : Salemba Medika.

Keperawatan.

Purwandari, Retno 2010. Konsep Keluarga Berencana. Bandung.

SDKI. 2012. Survey Demografi Kesehatan Indonesia. Jakarta.

Suparyanto. 2011. Wanita Usia Subur. Wordpress. Com Diakses tanggal $19 \quad$ Oktober 2011.

Vemale. 2013. Tanda-tanda Wanita Sedang Dalam Masa Subur. Jakarta : Alfabeta

Wawan. 2010. Pengetahuan, Sikap dan Perilaku Manusia. Yogyakarta : Nuha

Medika.

Wawan. 2012. Teori dan Pengukuran Pengetahuan, Sikap, dan Perilaku Manusia.Jakarta :

Nuha Medika. 